\title{
The (In)applicability of the Right of Innocent Passage in the Gulf of Finland - Russia's Return to a Mare Clausum?
}

\section{Alexander Lott}

Norwegian Centre for the Law of the Sea, Faculty of Law, University of Tromsø - UiT The Arctic University of Norway, Tromsø, Norway; School of Law, University of Tartu, Tallinn, Estonia

\begin{abstract}
The Gulf of Finland has one of the busiest shipping routes globally and is the main export channel for Russian oil and gas. The Russian Federation has not closed its territorial sea for the east-west passage of ships to and from its ports. However, it has blocked over the past dozen years the north-south passage of an Estonian-Finnish commercial ferry line that has not received the Russian Federation's permission for crossing its territorial sea. The Russian Federation's permit-based passage regime caused the closure of that ferry line in 2007 and reportedly still hinders its re-establishment. In this context, the Russian Federation's practice on the right of innocent passage through its territorial sea in the Gulf of Finland resembles the Soviet Union's practice prior to the 1989 Jackson Hole statement.
\end{abstract}

\section{Keywords}

innocent passage - straight baselines - territorial sea - Russian Federation - Gulf of Finland

\section{Introduction}

The right of innocent passage forms one of the cornerstones of the legal framework on navigation. ${ }^{1}$ It has implications for global trade, transport, and security, as well as the marine and coastal environment. From the perspective of commerce and international relations, it is important to have legal certainty regarding the rules regulating maritime navigation.

This article seeks to establish whether the Russian Federation has imposed any unlawful limitations to the enjoyment of this fundamental principle of international law. In this context, the study examines the international legal framework applicable to navigation in the Russian Federation's maritime area in the Gulf of Finland. For this purpose, it also raises the question of whether the Russian Federation's maritime area in the centre of the Gulf of Finland proper comprises its internal waters.

The present study is geographically limited, and it focuses specifically on the Russian Federation's approach to navigation rights and freedoms in the Gulf of Finland. It first elaborates on the characteristics of the Gulf of Finland and adopts a historical method to briefly explain the Soviet Union's and the Russian Federation's approaches to the passage regime of foreign ships in the Gulf of Finland until 2000. The baselines and maritime zones of the Russian Federation in the Gulf of Finland are examined next in order to discuss the legality of the Russian Federation's permit-based passage regime in that maritime area. The article also provides a case study on the impact of the permit-based passage regime to foreign ships using the example of the Estonian-Finnish Vironia commercial ferry line, which soon after its opening was declined the right of innocent passage in the Russian Federation's

\footnotetext{
${ }^{1}$ This is a revised and expanded version of the author's article which appeared first in Estonian, see A Lott, 'Rahumeelse läbisõidu õigus Venemaa Föderatsiooni Soome lahe vetest' (2017) 25(7) Juridica 501-511. The author would like to thank the anonymous reviewers and Pierre Thévenin as well as Susan Rolston for their comments on this work.
} 
maritime area and consequently had to be closed in 2007. Finally, the current impediments to international navigation in the Gulf of Finland are put in a broader context and compared with developments in the Russian Arctic and the Sea of Azov as the basis for a discussion of how the Russian Federation has balanced the application of the concepts of mare liberum and mare clausum in its maritime areas.

\section{Characteristics of the Gulf of Finland}

The passage through the Gulf of Finland - the Viro Strait - is less than 24 nautical miles (M) wide as measured from the Estonian and Finnish straight baselines. The Viro Strait spans the maritime area that lies between Osmussaar Island in the west and Vaindloo Island in the east. This narrow maritime area meets the geographic and functional criteria of an international strait as it leads to the territorial sea and exclusive economic zone (EEZ) of a third State, that is, the Russian Federation, and is heavily used for international navigation (see Figures 1 and $2)^{2}$

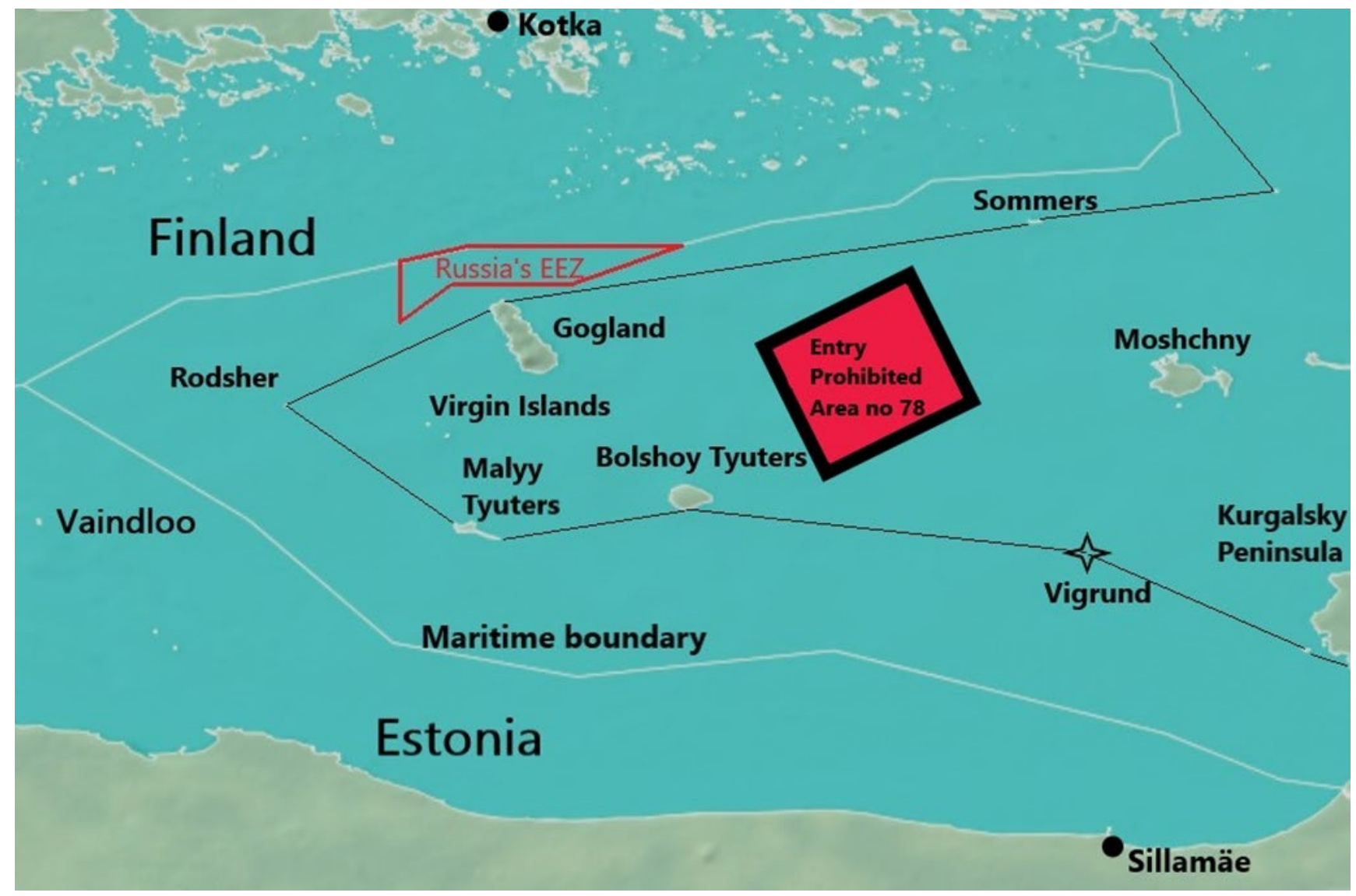

FIGURE 1 Map of the Russian Federation's potential updated system of straight baselines in the Gulf of Finland

SOURCE: Marineregions.org, 'Russia', Flanders Marine Institute (VLIZ) (2020) available at https://www.marineregions.org/eezdetails.php?mrgid=5690\&zone=eez_12nm; accessed 12

\footnotetext{
${ }^{2}$ The term 'international strait' is not necessarily synonymous with 'straits used for international navigation'. For the purpose of this article, an international strait constitutes such natural sea passage that is used for international navigation, connects two larger maritime areas and is not more than $24 \mathrm{M}$ wide (see Article 35(b)) as measured from coast to coast or from baseline to baseline and in regard of which international vessels and/or air traffic is safeguarded under the United Nations Convention on the Law of the Sea (Montego Bay, 10 December 1982, in force 16 November 1994) 1833 UNTS 396.
} 
October 2020. The map has been modified by the author so as to depict the potential updated system of straight baselines in the Russian Federation's maritime area and indicative references to the names of, inter alia, the States, ports, islands, peninsulas, maritime zones, and restricted areas mentioned in this article. See also Office for Ocean Affairs and the Law of the Sea, The Law of the Sea Baselines: National Legislation with Illustrative Maps (United Nations, New York, 1989) 352; see also Navionics Europe HD (n 36).

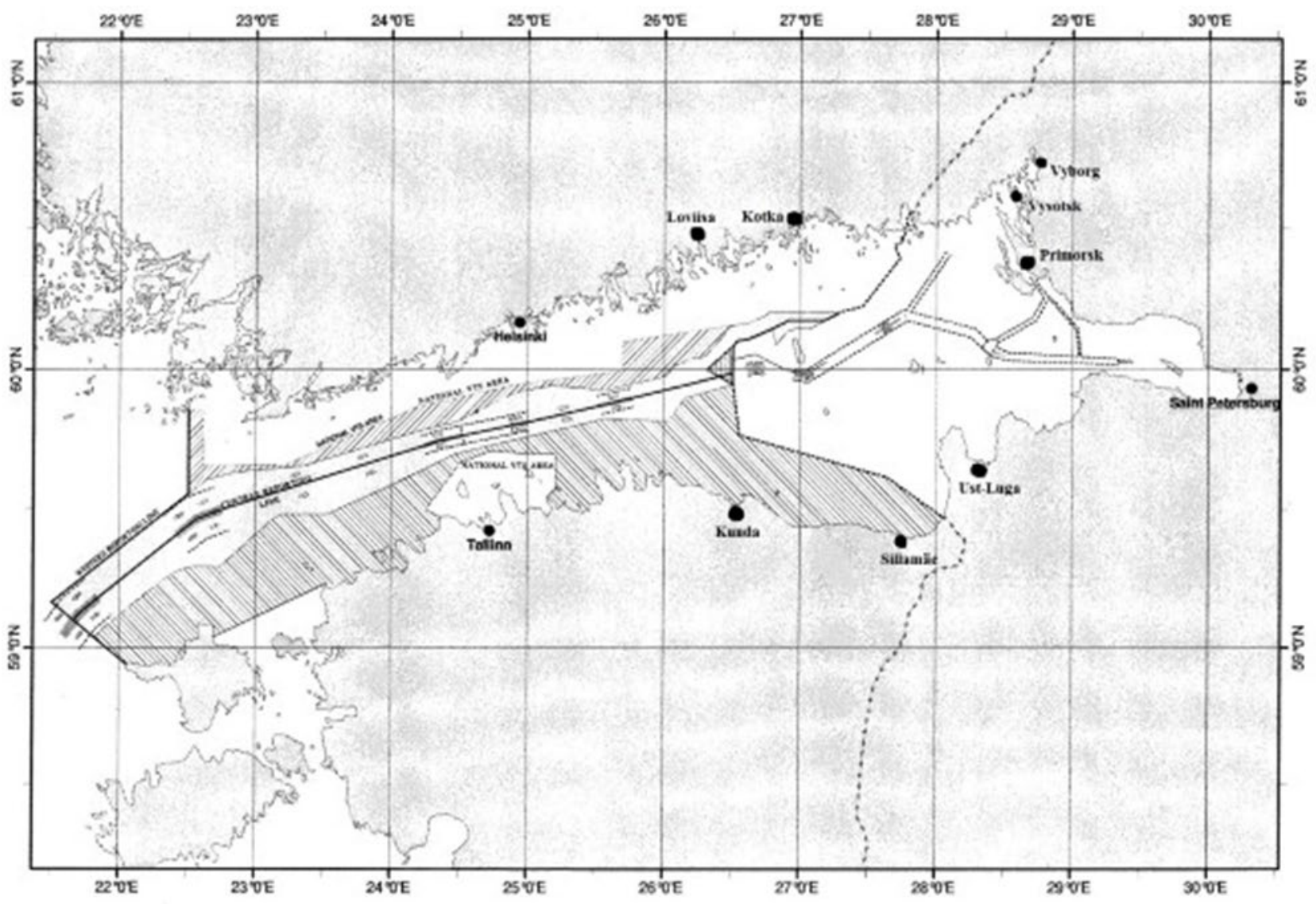

FIGURE 2 Ports and maritime areas of the coastal States of the Gulf of Finland

SOURCE: Rosmorport, 'General information/VTS Coverage areas', 'VTS services' available at http://www.rosmorport.com/spb_serv_nav.html; accessed 12 October 2020. The map serves an illustrative purpose and is modified by the author to include the names of the ports mentioned in this article.

Finland and Estonia have ensured the freedom of navigation and freedom of overflight through and over the Viro Strait by the establishment in 1994 of a 6-M-wide EEZ corridor. Both States agreed to limit the width of their territorial sea in the Viro Strait, so that it extends no closer than $3 \mathrm{M}$ to the median line. ${ }^{3}$ Hence, the Viro Strait meets the characteristics of an

\footnotetext{
${ }^{3}$ Exchange of Notes Constituting an Agreement on the Procedure to be followed in the Modification of the Limits of the Territorial Waters in the Gulf of Finland (Tallinn/Helsinki, 4 May 1994, in force 31 July 1995) 1887 UNTS 223.
} 
Article 36-category of strait under the United Nations Convention on the Law of the Sea (LOSC). ${ }^{4}$

Therefore, legally speaking, the Gulf of Finland spans the maritime area which is located east of the Viro Strait. The Gulf of Finland proper lies between the coastal cities of Loviisa (NW), Kunda (SW), Narva-Jõesuu (SE), St Petersburg (E), Vyborg (NE). Its coastal States are Finland, the Russian Federation, and Estonia.

Since 2017, the passenger flows of the Port of Helsinki, located on the northern coast of the Viro Strait, have been annually either slightly above or similar to that of the Port of Dover, the busiest passenger port in Europe. ${ }^{5}$ At the same time, the Port of Tallinn on the southern coast of the Viro Strait has been the third largest passenger port in Europe (this position has been often shared with the Port of Messina in Sicily). ${ }^{6}$ The main factor contributing to the growth of the two passenger ports is the frequent commuting across the strait by the residents of Helsinki and Tallinn.

In addition, the Viro Strait is crossed by the busy shipping lanes that connect the Russian Federation's maritime area with the Baltic Sea proper. The east-west shipping traffic through the Viro Strait exceeds that of all other straits in the Baltic Sea, including the Danish Great Belt and Øresund between Sweden and Denmark. ${ }^{7}$ This is largely due to the fact that the Gulf of Finland is the main export route for Russian oil and gas. The Russian Federation's major ports on the coasts of the Gulf of Finland include

- Ust-Luga (2nd largest Russian port, about 104 million tons of cargo handled in 2019),

- Primorsk (5th largest Russian port, approximately 61 million tons of cargo handled in 2019),

- Big Port St Petersburg (6th largest Russian port, approximately 60 million tons of cargo handled in 2019),

- Vysotsk (13th largest Russian port, 19.4 million tons of cargo handled in 2019), and

- naval port Kronstadt. ${ }^{8}$

In addition, St Petersburg has been one of the most popular destinations in Europe among cruise ship passengers. ${ }^{9}$

Of the three coastal States, the Russian Federation's maritime area in the Gulf of Finland proper is the largest. This is due to the 1940 Peace Treaty between Finland and the

\footnotetext{
${ }^{4}$ Due to the existence of the Russian Federation's tiny EEZ in the Gulf of Finland proper (see infra section 'The Russian Federation's Maritime Zones in the Gulf of Finland'), the high seas freedoms that currently apply in the Viro Strait under Article 36 of the LOSC would be replaced with the regime of transit passage (Article 37) if the EEZ corridor was abolished.

${ }^{5}$ Port of Helsinki, 'The world's busiest passenger port', Press Announcement (29 May 2018) available at portofhelsinki.fi/en/emagazine/worlds-busiest-passenger-port; accessed 12 October 2020; see also 'Maritime passenger statistics', Eurostat, available at https://ec.europa.eu/eurostat/statisticsexplained/index.php?title=Maritime_passenger_statistics\&oldid=504599; accessed 12 October 2020.

${ }^{6}$ Port of Tallinn, 'Port of Tallinn 2019 Q4 and full year passenger and cargo flows', Press Announcement (10 January 2020) available at https://www.ts.ee/en/port-of-tallinn-2019-q4-and-full-year-passenger-and-cargoflows/; accessed 12 October 2020; see also Eurostat statistics (n 5).

${ }^{7}$ See the HELCOM Map and Data Service available at http://maps.helcom.fi/website/mapservice/; accessed 12 October 2020.

${ }^{8}$ See D Elagina, 'Volume of cargo handled in Russia in 2019, by largest port', Statista (16 January 2020) available at https://www.statista.com/statistics/1023550/russia-cargo-throughput-by-port/; accessed 12 October 2020.

9 'Passenger Port of St. Petersburg summed up 2019 navigation results', PortNews (2 December 2019) available at https://en.portnews.ru/news/287873/; accessed 12 October 2020.
} 
Soviet Union, ${ }^{10}$ under which Finland ceded its islands in the centre of the Gulf of Finland proper to the Soviet Union. They are now under the sovereignty of the Russian Federation. As discussed below, this maritime area was considered by the Soviet Union mostly as its 'closed sea'.

\section{Right of Innocent Passage in the Eastern Gulf of Finland from 1920s to 2000}

The permit-based passage regime of the Soviet Union/Russian Federation has been applicable in the territorial sea in the Gulf of Finland at least since the middle of the twentieth century, albeit in multiple variations. Erik Franckx notes that the Soviet Union has required such permission from foreign warships since the late 1950s. ${ }^{11}$ It is less known that a permit-based passage regime was applicable in some small maritime pockets (e.g., near Kotlin Island) in the eastern part of the Gulf of Finland under the 1924 instructions for the navigation of ships in coastal waters within artillery range of coastal batteries in peacetime. Article 2 provided that both Soviet and foreign commercial vessels have the right to unhindered passage, except in special zones, within the limits of territorial waters. ${ }^{12}$ In the Baltic Sea, these restrictions could have been used only for the defence of Petrograd since the Soviet Union's maritime area was limited to a small stretch of sea west of Petrograd (the coast to the northwest of Petrograd as well as the islands in the middle of the Gulf of Finland proper were at that time still part of the Finnish territory).

Gene Glenn has referred to an incident which points to the potential applicability of a broader permit-based passage regime to commercial vessels sailing in the Gulf of Finland in the second half of 1940s. ${ }^{13}$ The incident involved a Swedish fishing vessel, Hamnfjord, that sailed in 1948 into the Gulf of Finland where she was taken into custody by the Soviet Union. The ship and her crew were released after being interrogated by the Soviet Union's Coast Guard.

The Soviet Union claimed that Hamnfjord had unlawfully entered its coastal defence zone (also known as maritime frontier zone) and disregarded orders to stop. ${ }^{14}$ Pursuant to the Soviet Union's 1927 instructions, ${ }^{15}$ the Soviet Union's Coast Guard proceeded from the understanding that they are allowed to board, inspect, and detain, where necessary (particularly if the ship is suspected of having engaged in fishing), all non-military vessels that enter the coastal defence zone.

The Soviet Union alleged in its diplomatic note to Sweden that the crew of Hamnfjord had been interrogated since they violated its laws on territorial sea. ${ }^{16}$ This created legal uncertainty since Hamnfjord was sailing outside the 4-M-limit as measured from the Soviet

\footnotetext{
${ }^{10}$ Peace Treaty between the Soviet Union and Finland (Moscow, 12 March 1940, in force 13 March 1940) (1940) 34(3) American Journal of International Law (Supplement: Official Documents) 127-131; see also Treaty of Peace with Finland (Paris, 10 February 1947, in force 16 September 1947), (1948) 42(3) American Journal of International Law (Supplement: Official Documents) 203-223, Article 1.

${ }^{11}$ E Franckx, 'The U.S.S.R. position on the innocent passage of warships through foreign territorial waters' (1987) 18(1) Journal of Maritime Law and Commerce 33-65, at pp. 56-58, 63.

${ }^{12}$ Instructions for the navigation of ships in coastal waters within artillery range of coastal batteries in peacetime ('Инструкции для плавания судов в береговых водах в пределах зоны обстрела береговых батарей в мирное время'), Order no 897 from the Revolutionary Military Council of 5 July 1924, Article 2. This provision is quoted in A Uustal, Международно-правовой режим территориальных вод (Tartu State University Press, Tartu, 1958), at p. 61. For the translation, see WE Butler, The Soviet Union and the Law of the Sea (The Johns Hopkins Press, Baltimore/London, 1971) 50-51.

${ }^{13}$ G Glenn, 'Notes and comments: The Swedish-Soviet territorial sea controversy in the Baltic' (1956) 50(4)

American Journal of International Law 942-949, at pp. 942-947.

${ }^{14}$ Ibid., at p. 942.

${ }^{15}$ Butler (n 12), at p. 52.

${ }^{16}$ Glenn (n 13), at p. 942
} 
Union's coast. The Soviet Union's coastal defence zone extended to $12 \mathrm{M}$ since $1927,{ }^{17}$ whereas its territorial sea was $4 \mathrm{M}$ wide, as first fixed in the 1920 Tartu Peace Treaty between Finland and the Soviet Russia pursuant to Nordic regional customary law. ${ }^{18}$

Thus, Sweden requested in its diplomatic note information on whether the Soviet Union had established a 12-M-wide territorial sea, and referred to the right of innocent passage that ought to apply in the territorial sea. ${ }^{19}$ The Soviet Union did not respond to this enquiry immediately, but acknowledged two years later, in a 1950 diplomatic note to Sweden, that it had extended the width of its previously 4-M-wide territorial sea in the Baltic Sea to $12 \mathrm{M} .^{20}$

The Hamnfjord incident appears to indicate that already by the 1940s, the Soviet Union was denying innocent passage in its territorial sea to foreign ships, including commercial ships, if they had failed to request prior permission. On the other hand, the Soviet Union's later diplomatic statements and the views of Soviet scholars, as expressed in the relevant legal literature, were less unequivocal on this matter. In his review of Soviet textbooks of the 1950s and 1960s, Butler shows that the views of numerous Soviet jurists favoured a narrow interpretation of the scope of innocent passage that only applies strict requirements to commercial ships in the territorial sea. ${ }^{21}$ Yet even in the 1950s other Soviet writers disagreed with such statements and claimed that a coastal State cannot hamper the innocent passage of foreign commercial ships. ${ }^{22}$ A liberal understanding of the right of innocent passage took root in the Soviet publications in the 1970s and 1980s. Franckx has pointed out that many Soviet authors claimed years before the 1989 Jackson Hole statement ${ }^{23}$ that foreign ships, including warships, enjoy the right of innocent passage, even if they have not requested the coastal State's prior permission. ${ }^{24}$ Yet the views of Soviet professors were far from unanimous on this question. For example, Abner Uustal, professor of international law at the University of Tartu, found in 1984 that due to the Soviet Union's security considerations, it is in any case necessary to require from foreign warships a prior authorisation for exercising the right of innocent passage. ${ }^{25}$

The Soviet Union had guaranteed under its 1960 statute on the protection of its boundary the right of innocent passage to foreign non-military vessels in its territorial sea (excluding internal waters), while subjecting foreign warships to the permit-based passage regime. ${ }^{26}$ By contrast, as of the 1989 Jackson Hole statement, the Soviet Union and its successor State, the Russian Federation, have been expected to guarantee the right of innocent passage to all foreign ships absent prior notification or a request for authorisation. ${ }^{27}$

According to the 1989 statement, all ships, including warships, regardless of cargo, armament or means of propulsion, enjoy the right of innocent passage through the territorial sea, for

\footnotetext{
${ }^{17}$ LB Schapiro, 'The limits of Russian territorial waters in the Baltic' (1950) 27 The British Yearbook of International Law 439-448, at p. 447.

18 Treaty of Peace between Finland and Soviet Government of Russia (Tartu, 14 October 1920, in force 31 December 1920) 3 LNTS 65, Article 3.

${ }^{19}$ Glenn (n 13), at p. 943.

${ }^{20}$ Ibid., at p. 944.

${ }^{21}$ Butler (n 12), at pp. 54-57.

${ }^{22}$ Ibid., at pp. 56-57.

${ }^{23}$ Joint Statement by the United States of America and the Union of Soviet Socialist Republics, 'Uniform Interpretation of Rules of International Law Governing Innocent Passage' (Jackson Hole, 23 September 1989) (1989) 14 Law of the Sea Bulletin 12 available at

http://www.un.org/depts/los/doalos_publications/LOSBulletins/bulletinpdf/bulE14.pdf; accessed 12 October 2020.

${ }^{24}$ Franckx (n 11), at pp. 37-40.

${ }^{25}$ A Uustal, Rahvusvaheline oigus (Eesti Raamat, Tallinn, 1984) 260, 263.

${ }^{26}$ Butler (n 12), at pp. 52-53.

${ }^{27}$ See, e.g., K Hakapää and EJ Molenaar, 'Innocent passage - past and present' (1999) 23(2) Marine Policy 131145 , at p. 143 .
} 
which neither prior notification nor authorisation is required. ${ }^{28}$ The Russian Federation has clearly stipulated this also in its domestic law (the 1989 statement itself is legally nonbinding). The 1998 Federal Act on the internal maritime waters, territorial sea and contiguous zone provides that foreign ships, foreign warships and other government ships enjoy the right of innocent passage through the territorial sea for which a prior notification or request for authorisation is not required. ${ }^{29}$ Such a regulation conforms with the rules on innocent passage as stipulated under Article 24(1) of the LOSC. ${ }^{30}$ However, the Russian Federation's recent State practice, as discussed below, calls into question the conformity of its permit-based regime in the Gulf of Finland with the right of innocent passage under its domestic legal acts and the LOSC.

\section{The Russian Federation's Maritime Zones in the Gulf of Finland}

The Russian Federation's system of straight baselines in the Gulf of Finland is based on the Soviet Union's 1985 decree on a list of geographic coordinates determining the position of its baselines in the Baltic Sea. ${ }^{31}$ The Russian Federation does not appear to have revised the coordinates, or notified the United Nations about any modifications to said decree. Thus, one may expect that this decree is still in force.

According to the 1985 decree, the starting point of the Soviet Union's straight baselines was on the northeastern coast of the Gulf of Finland from where the straight baselines proceeded to Vaindloo Island and onwards along the Estonian coast, connecting the outermost islands. ${ }^{32}$ The last segment of the Soviet Union's straight baselines in the Baltic Sea connected the Sõrve Peninsula on Saaremaa Island in Estonia with the Ovisi Cape in the Latvian Courland Peninsula. The Soviet Union used normal baselines south of the Ovisi Cape in the remaining parts of its eastern coast of the Baltic Sea. ${ }^{33}$

If the Russian Federation still measures the breadth of its territorial sea based on the system of straight baselines as established under the 1985 decree, then its extent is by now considerably reduced. Due to the restoration of Estonia's independence in 1991, the Soviet Union's/Russian Federation's system of straight baselines was interrupted and broke off in the middle of the baseline segment that connected Rodsher Island with Vaindloo Island, which is part of the Estonian territory.

For this reason, the Estonian official nautical charts depict the Russian Federation's last straight baseline segment in the Gulf of Finland as a broken line heading from Rodsher Island to Vaindloo Island. The baseline is abruptly cut at the point where it reaches the

\footnotetext{
${ }^{28}$ Ibid.

${ }^{29}$ See Federal Act on the internal maritime waters, territorial sea and contiguous zone of the Russian Federation, adopted 16 July 1998, in force 31 August 1998, Articles 12-13 available at

https://www.un.org/depts/los/LEGISLATIONANDTREATIES/PDFFILES/RUS_1998_Act_TS.pdf; accessed 12 October 2020.

${ }^{30}$ The coastal State cannot deny innocent passage through its territorial waters, inter alia, to tankers, nuclearpowered ships and ships carrying nuclear or other inherently dangerous or noxious substances or materials (LOSC (n 2), Article 23). However, in conformity with Article 25(1) of the LOSC, the coastal State may take the necessary steps in its territorial sea to prevent passage which is not innocent. This provision grants coastal States necessary discretion in applying proportional measures.

${ }^{31}$ Council of Ministers of the Soviet Union, Decree no. 4450 'On the confirmation of a list of geographic coordinates determining the position of the baseline in the Arctic Ocean, the Baltic Sea and Black Sea from which the width of the territorial waters, economic zone and continental shelf of the U.S.S.R. is measured', (Moscow, 15 January 1985) available at http://www.un.org/Depts/los/LEGISLATIONANDTREATIES/PDFFILES/RUS_1985_Declaration.pdf; accessed 12 October 2020.

${ }^{32}$ Ibid., at points $1-32$.

${ }^{33}$ Ibid., at points $31-32$.
} 
Estonian maritime boundary. ${ }^{34}$ In effect, the Russian Federation's system of straight baselines, as established under the 1985 decree, are now relevant only to the extent that it connects the Russian islands of Sommers, Gogland, and Rodsher with the Russian mainland on the northern coast of the Gulf of Finland. Hence, it does not form an integral whole. Instead, it constitutes an extraordinary incomplete system of straight baselines. Presumably, such an incomplete system of straight baselines would not meet the requirement according to which straight baselines need to join 'appropriate points' (Article 7(1) of the LOSC).

An incomplete system of straight baselines does not allow a State to clearly establish the outer limit of internal waters in a relevant maritime area. In the case of the Gulf of Finland, the internal waters regime ought to apply to the maritime area that falls landward side of the straight baselines that connect Sommers, Gogland, and Rodsher islands. If applicable, such a system of baselines would blur the lines between the Russian Federation's territorial sea and internal waters, rendering the relevant domestic legislation incompatible with Article 7 of the LOSC. Hence, the 1985 decree no longer can be considered effective in the Gulf of Finland in whole, or in part. The maritime area falling to the landward side of the Russian Federation's islands in the middle of the Gulf of Finland proper should be considered as its territorial sea, not internal waters.

Notably, the Russian Federation's practice does not indicate whether or not the incomplete system of straight baselines is effective in the Gulf of Finland. According to the Federal Port Authority Rosmorport, the operational area of its vessel traffic services (VTS) system in the Gulf of Finland is limited to the Russian Federation's territorial sea and ports. Rosmorport does not make any other explicit reference to internal waters in the Gulf of Finland proper. ${ }^{35}$ According to Navionics charts, which are usually accurate in depicting maritime zones and straight baselines in the northern Baltic Sea, the Russian Federation's maritime area in the middle of the Gulf of Finland does not include any straight baselines. ${ }^{36}$

If the Russian Federation drew a new system of straight baselines in the Gulf of Finland, then it could potentially use Tyuters Islands, Vigrund island/rock, and Kurgalsky Peninsula , arguably, as appropriate points for creating new baseline segments and closing the currently incomplete system of straight baselines in the Gulf of Finland. ${ }^{37}$ Many maps neglect the existence of Vigrund island/rock; as a result, Vigrund's territorial sea is mistakenly replaced with an EEZ north of Narva Bay. ${ }^{38}$ However, Vigrund has great significance for the establishment of a new system of straight baselines. It is located approximately $8.5 \mathrm{M}$ west of the Kurgalsky Peninsula and $16.5 \mathrm{M}$ east of Bolshoy Tyuters. Vigrund is above water at high tide and a lighthouse has been stationed there for at least a hundred years. ${ }^{39}$ Russian geographers do not hold an unanimous view on whether Vigrund constitutes an island or a

\footnotetext{
${ }^{34}$ See the Estonian Maritime Administration's chart no. 300, 'Soome laht: Paldiskist Narvani'; see also Charts of Estonia, vol 1, 'Gulf of Finland: Suurupi Peninsula to Narva' (Estonian Maritime Administration, Tallinn, 2015), at p. 2.

${ }^{35}$ See Rosmorport, North-Western Basin Branch, 'VTS coverage areas' available at http://www.rosmorport.com/spb_serv_nav.html; accessed 12 October 2020; see also the Russian Federation's nautical chart 'Восточная часть Финского залива', scale 1:250 000, 19 July 1997 available at http://balticborder.com/wp-content/uploads/2013/05/fin_zaliv-vostok-restriction-area2.jpg; accessed 12 October 2020.

${ }^{36}$ Navionics Europe HD, Vers. 7.1.2 available at https://webapp.navionics.com/?lang=en\#boating@7\&key=wmfmJshneD; accessed 12 October 2020.

${ }^{37}$ See Figure 1. The map depicts the potential updated system of straight baselines in the Russian Federation's maritime area.

${ }^{38}$ See, e.g., Marineregions.org, 'Russia', Flanders Marine Institute (VLIZ) 2020 available at https://www.marineregions.org/eezdetails.php?mrgid=5690\&zone=eez_12nm; accessed 12 October 2020. ${ }^{39}$ Vigrund lighthouse was mentioned already in the 1920 Finnish-Soviet Peace Treaty (n 18), Article 3(4).
} 
rock, ${ }^{40}$ but in either case it could serve as an appropriate point for the establishment of a new system of straight baselines.

On the other hand, it is doubtful if such a new system of straight baselines would meet the requirements of Article 7(1) and 7(3) of the LOSC. According to these provisions, the method of straight baselines may be employed if it connects appropriate points on a fringe of islands along the coast in its immediate vicinity and the sea areas lying within the lines is sufficiently closely linked to the land domain to be subject to the regime of internal waters. The Russian Federation's islands in the middle of the Gulf of Finland proper depart considerably from the general direction of its mainland coast. The westernmost Rodsher Island is located approximately $43 \mathrm{M}$ away from the nearest points on the southern and northern coasts of the Russian mainland (see Figure 1).

In addition, the Gulf of Finland proper includes the Russian Federation's EEZ that was established initially as a high seas corridor pursuant to the maritime boundary treaties concluded between Finland and the Soviet Union in 1940, 1965, and 1985. ${ }^{41}$ The existence of this tiny Russian EEZ in the Gulf of Finland is not widely acknowledged in Estonia and Finland. For example, the Estonian Maritime Administration has had no information about the existence of the Russian Federation's EEZ in the Gulf of Finland. ${ }^{42}$ Similarly, Estonia and Finland presumed when establishing their EEZ corridor in the Viro Strait that the right of innocent passage would apply (instead of transit passage) in the Viro Strait that leads to the Russian Federation's maritime area (see Articles 17 and 45(1)(b) of the LOSC). ${ }^{43}$

The Russian Federation's EEZ in the Gulf of Finland is approximately $9 \mathrm{M}$ long and mostly about $2 \mathrm{M}$ wide (at its widest point close to $4 \mathrm{M}$ ). ${ }^{44}$ This tiny EEZ borders Gogland Island, reaching as close to it as $2 \mathrm{M} .{ }^{45}$ It has great significance for navigation, since its existence implies that if Estonia and Finland decided to extend the outer limit of their territorial sea to the maximum extent in the Viro Strait, thus abolishing the current 6-M-wide EEZ corridor, then ships and aircraft would be entitled to the right of transit passage for navigating to and from the Russian Federation's maritime area in the eastern Gulf of Finland (Article 38 of the LOSC). The tiny Russian EEZ is also crossed by the most direct navigation route between the Sillamäe Port in eastern Estonia and the Kotka Port in eastern Finland. During their voyage, within the limits of the Russian Federation's EEZ next to Gogland Island, under Articles 58(1) and 87(1)(a) of the LOSC, ships are entitled to freedom of navigation, including the right to stop and anchor.

Therefore, ships crossing the Russian Federation's territorial sea and EEZ in the Gulf of Finland are entitled to the right of innocent passage and freedom of navigation. It is relevant to assess next if the Russian Federation has in practice respected the right of innocent passage through its territorial sea, particularly in the light of the closure in 2007 of the Vironia ferry line that had to cross the Russian Federation's maritime area while navigating between the Estonian and Finnish ports.

\footnotetext{
${ }^{40}$ See Russian Geographical Society, 'Complex Expedition "Hogland”, Islands' available at https://www.rgo.ru/en/projects/expeditions/complex-expedition-hogland/islands; accessed 12 October 2020.

${ }^{41}$ See further in AG Oude Elferink, The Law of Maritime Boundary Delimitation: A Case Study of the Russian Federation (Martinus Nijhoff, Dordrecht, 1994) 183-186, at p. 189; see also A Lott, The Estonian Straits: Exceptions to the Strait Regime of Innocent or Transit Passage (Brill, Leiden/Boston, 2018) 74-75.

${ }^{42}$ Lott (n 41), at p. 76.

${ }^{43}$ Ibid., at p. 75.

${ }^{44}$ Ibid., at p. 74.

${ }^{45}$ See Navionics Europe HD (n 36).
} 


\section{The Vironia Incident in the Gulf of Finland and Its Aftermath}

The significance of the right of innocent passage for global maritime transport was illustrated by an incident involving the Estonian-flagged ship Vironia, which transported goods and passengers between Sillamäe and Kotka ports in the eastern Gulf of Finland. ${ }^{46}$ This ferry line was launched by the Saaremaa Shipping Company in February $2006 .{ }^{47}$ The roll-on/roll-off ferry Vironia had a capacity to transport 370 passengers and 940 lane meters of trucks and cars, many of which were heading to the Russian Federation. ${ }^{48}$ Vironia made 10 weekly departures and its schedule was increased to 12 weekly departures during the summer season. ${ }^{49}$

After the ferry line was launched, its operator still had consultations with the Russian Federation authorities about receiving permission to use the shortest route through its territorial sea for navigation. ${ }^{50}$ These negotiations were cancelled by the Russian Federation after Estonia relocated the Soviet World War II Bronze Soldier memorial from the city centre in Tallinn to the near-by military cemetery in April 2007. ${ }^{51}$ In the aftermath of this incident, the Russian Federation was not willing to resume negotiations over the right of passage of the passenger ferry through its maritime area in the Gulf of Finland proper. This led to the closure of the Vironia ferry line between the Estonian and Finnish ports since the navigation route around the Russian Federation's maritime area was not economically feasible. ${ }^{52}$ The distance between the two ports across the Russian Federation's maritime area is $70 \mathrm{M}$, whereas the round-about route is $90-\mathrm{M}$-long. ${ }^{53}$ The direct route between the two ports via the Russian Federation's maritime area would have been 2 hours shorter, which would have reduced fuel costs and increased competitiveness in comparison with the Tallinn-Helsinki ferry lines. ${ }^{54}$

Over the next years, attempts were made to relaunch the ferry line between the ports of eastern Estonia and eastern Finland. ${ }^{55}$ In a 2015 maritime assembly of the Gulf of Finland's coastal States in Sillamäe, a member of St Petersburg's maritime council, Mr Andrei Berezkin, found that the ferry line's use of the Russian Federation's maritime area in the eastern Gulf of Finland had so far not been subject to proper consideration at a sufficiently high level by Russian authorities. ${ }^{56}$ In 2016, representatives of the port town Loviisa in eastern Finland visited Kunda and Sillamäe ports in eastern Estonia. This was followed by the eastern Estonian local government's officials' visit to the Finnish port towns Kotka and Loviisa in order to agree on the timeframe for relaunching the ferry line between eastern Finland and eastern Estonia. ${ }^{57}$ For this purpose, they still considered it necessary to first acquire permission from the Russian Federation authorities to navigate through its territorial sea in the Gulf of Finland. ${ }^{58}$

\footnotetext{
${ }^{46}$ See, e.g., 'Päivittäinen laivaliikenne Kotkan ja Sillamäen välillä päättyy', Yle Uutiset (17 October 2007); J Niemeläinen, 'Kotkan ja Sillamäen välinen laivalinja lopettaa', Helsingin Sanomat (18 October 2007).

47 'Sillamäe-Kotka laevaliin teeb avareisi 17. veebruaril', Postimees (12 January 2006).

${ }^{48}$ Ibid.

49 'Sillamäe-Kotka laevaliin on Ida-Viru tänavune turismitegu', Logistikauudised (8 December 2006).

${ }^{50}$ Yle Uutiset 2007 (n 46); see also Figure 2.

${ }^{51}$ H Ellam, 'Pronksiöö tulemus: Sillamäe-Kotka laevaliin suletakse', Äripäev (17 October 2007).

52 Ibid.; see also Niemeläinen (n 46).

${ }^{53}$ G Romanovitš, 'Soome ja Eesti otsisid mereühenduse võimalusi', Põhjarannik (30 June 2016); see Figures 1 and 2 .

${ }^{54} \mathrm{~J}$ Eelmets, 'Sillamäe-Kotka laevaliini taastamine sõltub kokkuleppest Venemaaga', ERR Uudised (20

November 2015).

${ }^{55}$ See, e.g., 'Kotkan ja Viron välistä laivaliikennettä viritellään taas', Yle Uutiset (1 February 2011).

${ }^{56}$ Eelmets (n 54).

${ }^{57}$ G Romanovitš, 'Laevaliin vajab tasuvusanalüüsi', Põhjarannik (3 November 2016).

${ }^{58}$ Ibid.
} 
In 2018, a member of the council of the Finnish Kotka Port commented that the Finnish business sector was interested in relaunching the ferry line, but that it preferred to use for this purpose the Estonian Kunda Port, which is located west of Sillamäe Port. ${ }^{59}$ This was due to the perceived likelihood that the Russian Federation would not grant its permission for the ferry line to navigate through its territorial sea. In this context, the alternative route between Kunda and Kotka ports has a significant advantage as it would not necessarily cross the Russian Federation's territorial sea. In order to relaunch the ferry line, the Estonian and Finnish port authorities are currently considering another alternative route that would run between Kunda and Loviisa ports. ${ }^{60}$

\section{Potential Legal Basis of the Russian Federation's Permit-Based Passage Regime in the Gulf of Finland}

It follows from the foregoing discussion that the Russian Federation's permit-based regime for sailing through its territorial sea in the Gulf of Finland still hinders the re-establishment of a ferry line between the ports of eastern Finland and eastern Estonia. The potential legal basis of the permit-based passage regime is, however, subject to debate.

The Vironia incident exemplifies how the Russian Federation can make use of a permit-based passage regime in its maritime area to the detriment of international commerce. Pursuant to its national regulations, all ships entering the Russian Federation's maritime area in the Gulf Finland from the west, including by crossing the Estonian-Russian maritime boundary, are required to gain prior authorisation from its VTS centre. ${ }^{61}$ Its broader implications to international navigation are illustrated by the fact that a group of merchant ships are constantly waiting at the eastern end of the Estonian and Finnish EEZ corridor in the Gulf of Finland to receive permission to enter the Russian Federation's territorial sea and enter a port. ${ }^{62}$ This practice is permitted under international law based on the absence of a right of access to ports and a State's territorial sovereignty over its ports. ${ }^{63}$ However, it is doubtful if the permit-based regime is lawful in respect of commercial ships that simply seek to navigate under the right of innocent passage through the Russian Federation's territorial sea without calling on any Russian ports, as illustrated by the Vironia incident.

The Russian Federation could potentially subject the passage of foreign ships to the permit-based regime in the middle of the Gulf of Finland proper if this maritime area constitutes internal waters that also were considered internal waters prior to the establishment of straight baselines. This follows from Article 8(2) of the LOSC, which stipulates that where the establishment of a straight baseline in accordance with the method set forth in Article 7 of the LOSC has the effect of enclosing as internal waters areas which had not previously been considered as such, a right of innocent passage exists in those waters.

The maritime area in the middle of the Gulf of Finland proper hypothetically could constitute such internal waters where the right of innocent passage does not apply if the Soviet Union considered that maritime area as its internal waters prior to the adoption of the 1985 decree that established the Soviet Union's system of straight baselines, as examined above. Often such a claim may rest on the coastal State's historic title over a particular maritime area,

\footnotetext{
${ }^{59}$ A Reimer, 'Vähi ja Vallbaum ristasid laevaliini nimel mõõgad', Virumaa Teataja (17 January 2018).

${ }^{60}$ I Kuus, 'Kunda sadam kaalub laevaliini Loviisasse', ERR Uudised (11 May 2019).

${ }^{61}$ Rosmorport, North-Western Basin Branch, 'Terms and conditions of navigation VTS services with the use of

Saint Petersburg VTS' available at http://www.rosmorport.com/filials/spb_serv_nav/; accessed 12 October 2020.

${ }^{62}$ See Marine Traffic, 'Gulf of Finland' available at

https:/www.marinetraffic.com/en/ais/home/centerx:24.3/centery:59.3/zoom:8; accessed 12 October 2020.

${ }^{63}$ See Military and Paramilitary Activities in and against Nicaragua (Nicaragua v. United States of America), Judgment, ICJ Reports 1986, p. 111, para 213.
} 
for example, based on the historic bay concept. ${ }^{64}$ The Russian Federation does not claim to have such historic title over the maritime area in the middle of the Gulf of Finland, and there appears to be no actual basis for such a potential claim. The islands in the middle of the Gulf of Finland proper (Tyuters Islands, Rodsher, Gogland, Virgin Islands, Sommers) were Finnish territory prior to the 1940 Peace Treaty with the Soviet Union. ${ }^{65}$ Thus, the relevant maritime area belonged to Finland, not to the Soviet Union.

The 1985 decree lists the following maritime areas, the waters of which historically belong to the Soviet Union: the White Sea south of the line connecting Cape Svyatoy Nos with Cape Kanin Nos, the waters of Cheshskaya/Bay south of the line connecting Cape Mikulkin with Cape Svyatoy/Nos (Timansky), and the waters of Baidaratskaya Bay southeast of the line connecting Cape Yuribeisalya with Cape Belushy Nos. ${ }^{66}$ This list does not include any references to maritime areas of the Gulf of Finland. This, however, does not exclude the possibility that some bays in the eastern Gulf of Finland could be considered as long-standing internal waters where the right of innocent passage does not apply, for example, Vyborg Bay, Luga Bay, and the narrow maritime area near Kronstadt and St Petersburg.

Most Baltic Sea coastal States extended the breadth of their internal waters under the definition and scope of internal waters as established under the 1912 and 1938 Nordic Rules of Neutrality. Under these rules, the Scandinavian and Baltic States delimited the scope of their internal waters so that they included ports, entrances to ports, gulfs and bays, and the waters between those islands, islets and reefs which are not constantly submerged, and between the said islands, islets and reefs and the mainland. ${ }^{67}$ The Soviet Union as a nonneutral State did not contribute to the development of this regional customary international law in the Nordic region.

The Russian Federation may potentially exclude the right of innocent passage in its territorial sea under Article 21(1)(a) of the LOSC, which stipulates that the coastal State may adopt laws and regulations relating to innocent passage through the territorial sea in respect of the safety of navigation and the regulation of maritime traffic. The Russian Federation's permit-based passage regime in the Gulf of Finland can potentially serve a legitimate aim of ensuring safety of navigation in a particularly sensitive sea area that exhibits a high shipping traffic density around numerous islands and shoals that pose hazards for maritime transport.

It is possible that the permit-based passage regime is also aimed at safeguarding the Russian Federation's security interests. Gogland Island in the centre of the Gulf of Finland proper bears strategic importance, which is illustrated by the Russian Federation's recent investments into its military facilities on the island, including the construction of a helipad. However, it is not entirely clear if Article 21(1)(a) of the LOSC permits the coastal State to regulate the right of innocent passage based on general security considerations. One could argue that coastal States are allowed to prohibit innocent passage by foreign vessels in parts of the territorial sea that are near to features with security relevance. Clearly, the Russian Federation's fortifications on Gogland Island fall into this category. While under the abovementioned 1924 Revolutionary Military Council's instructions on innocent passage such special areas concerned prima facie Kotlin Island next to St Petersburg, the extension of the

\footnotetext{
${ }^{64}$ See further, e.g., RR Churchill and V Lowe, The Law of the Sea (Manchester University Press, Manchester, 1999) 44; CR Symmons, Historic Waters in the Law of the Sea: A Modern Re-Appraisal (Martinus Nijhoff, Leiden/Boston, 2008) 33.

${ }^{65}$ See 1940 Peace Treaty (n 10), Article 2.

${ }^{66} 1985$ decree (n 31), at p. 1.

67 'Declaration by Norway, Denmark and Sweden relative to the Establishment of Uniform Rules of Neutrality. Stockholm, 21.12.1912' (1913) 7(3) American Journal of International Law 187-191; see also 'Declaration between Denmark, Finland, Iceland, Norway and Sweden for the Purpose of Establishing Similar Rules of Neutrality. Stockholm, 27.05.1938' (1938) 32(4) American Journal of International Law 141-163; see also, e.g., Neutrality Act of Sweden ('Innefattande vissa neutralitetsbestämmelser'), No. 187, 27 May 1938, Section 2(2).
} 
Russian Federation's territory as a result of its title over the islands in the middle of the Gulf of Finland proper now potentially allow it to establish such special areas also near its military facilities around Gogland Island.

Although the permit-based passage regime may serve legitimate aims of safeguarding navigation safety, coastal State security and protection of marine environment, this does not mean that such a measure is lawful. Pursuant to Article 21(1) of the LOSC, such a measure needs to be in conformity with the provisions of the LOSC and other rules of international law. The permit-based passage regime in respect of ships that seek to continuously and expeditiously traverse the Russian Federation's territorial sea contradicts the LOSC rules on innocent passage, as discussed above. Thus, the Russian Federation's requirement of prior authorisation for the passage of foreign ships through its territorial sea fails to meet the criteria of Article 21(1)(a) of the LOSC. In the example of the Vironia incident and its aftermath, the said measure has amounted to completely extinguishing regular north-south traffic of foreign commercial vessels in the area.

Notably, under Article 15(1) of the 1998 Federal Act on the internal maritime waters, territorial sea and contiguous zone, the Russian Federation has reserved itself the right to establish areas in which navigation is prohibited and which are temporarily dangerous for navigation. The aim of such measures is to ensure the safety of navigation, safeguard 'State interests', and protect the environment. In this context, the Russian Federation has established 'Entry Prohibited Area No 78', which is located between Gogland Island and Moshchny Island (see Figure 1). ${ }^{68}$ This prohibited entry area is located east of the shortest navigation route of the Kotka-Sillamäe ferry line and thus would not affect it. ${ }^{69}$ The Russian Federation evidently cannot close its whole maritime area in the Gulf of Finland proper to navigation of foreign ships between Finland and Estonia.

The Russian Federation's prior permission requirement to the extent that it is applied in respect of ships that are not calling at the Russian Federation's port is not in conformity with the International Maritime Organization's (IMO) Resolution A.857(20), ${ }^{70}$ which the Russian Federation refers to as the legal basis for the VTS in the relevant maritime area. ${ }^{71}$ The Russian Federation's maritime area in the Gulf of Finland proper is almost entirely covered by the St Petersburg VTS, which complements the smaller VTS systems of the ports of UstLuga, Vysotsk, Vyborg, and Primorsk. ${ }^{72}$ Pursuant to the IMO resolution, a coastal State may exercise its discretionary right to establish and operate under its VTS a system of traffic clearances or VTS sailing plans, or both, in relation to priority of movements, allocation of space, mandatory reporting of movements in the VTS area, routes to be followed, speed limits to be observed, and adopt other appropriate measures. ${ }^{73}$ Yet such measures cannot, by the very nature of a VTS, exclude in toto the expeditious navigation of a particular ship through the territorial sea that is distant from the ports of a coastal State. This is especially the case if the ship poses a marginal threat to the marine environment, for example, a commercial ferry line. Pursuant to Annex 1 of Resolution A.857(20), the aim of a VTS is to improve the safety and efficiency of vessel traffic and to protect the environment. Thus, it cannot amount to extinguishing foreign vessel traffic completely.

\footnotetext{
${ }^{68}$ Navionics Europe HD (n 36).

${ }^{69}$ See Figure 1.

${ }^{70}$ Guidelines for Vessel Traffic Services, IMO Resolution A.857(20) adopted 27 November 1997, in force 3 December 1997, Annex 1: Guidelines and Criteria for VTS.

${ }^{71}$ Rosmorport, North-Western Basin Branch, 'Terms and conditions of navigation VTS services' available at http://www.rosmorport.com/spb_serv_nav.html; accessed 12 October 2020.

${ }^{72}$ Rosmorport, 'VTS coverage areas' (n 35).

${ }^{73}$ IMO Resolution A.857(20) (n 70), at Annex 1, para 2.3.3.
} 


\section{The Russian Federation's Restrictions to Navigation in a Broader Context}

The Russian Federation's restrictive approach to the passage rights and freedoms of foreign ships in the Gulf of Finland contradicts the terms of the LOSC. It lacks the legal basis for denying the right of innocent passage through its whole maritime area in the Gulf of Finland proper for ships that do not seek to enter its ports. As discussed above, foreign ships, including commercial vessels, were obliged to request prior permission for navigating through the Soviet Union's territorial sea since at least the 1940s. The 2007 Vironia incident illustrates that the Russian Federation has partially returned to such a practice by hampering the establishment and operation of regular ferry lines that seek to operate between the ports of eastern Estonia and eastern Finland. They have been unable to launch or continue their business due to the Russian Federation's permit-based passage regime. This has a direct negative impact on commerce, regional development and international relations in the Gulf of Finland region. This practice also appears to be discriminatory, since there have been no reports about similar refusals to the exercise of the right of innocent passage by other nongovernmental ships that have sailed between eastern Estonia and eastern Finland via the Russian Federation's territorial sea.

The Russian Federation has not presented a public explanation on why and on what legal basis it requires prior permission from some foreign ships that seek to traverse its territorial sea in the Gulf of Finland proper. Thus, the Vironia incident raises the question of whether or not Estonia and Finland should protest or otherwise object to the Russian Federation's permit-based passage regime in the Gulf of Finland.

In 2017, the Estonian Ministry of Foreign Affairs commented that it has not deemed it necessary to establish a position on the legality of the Russian Federation's practice in setting restrictions to navigation of foreign ships in the Gulf of Finland as operators at that time had not shown any interest in relaunching the ferry line between Sillamäe and Kotka ports. ${ }^{74}$ The ministry reiterated this position in $2020 .{ }^{75}$ On the other hand, one should acknowledge that, as explained above, ${ }^{76}$ local governments, port authorities, and potential operators have actively sought to relaunch a ferry line between eastern Estonia and eastern Finland throughout the past ten years and, according to media reports, such efforts are also presently underway.

For the smooth operation of global transport of goods and passengers, it is important that coastal States do not apply any illegal restraints on the exercise of the right of innocent passage. The Russian Federation tends to restrict navigational rights and freedoms not only in its maritime areas in the Baltic Sea, but also in the Arctic and the Black Sea. The main reason for this appears to be shifts in its security and policy-related interests. However, unlike the Vironia incident in the Baltic Sea and the Kerch Strait incident in the Black Sea, ${ }^{77}$ the restriction of navigation rights and freedoms in the Northern Sea Route is not rooted in a reactionary policy, but rather on a conceptually different interpretation of the LOSC, especially Article 234, as compared with other States, and its ramifications for the passage of foreign ships in ice-covered areas. The impediments to navigation that the Russian Federation has set in respect of the Northern Sea Route in the Arctic have triggered protests from States

\footnotetext{
${ }^{74}$ Comment obtained from the Director General of the Legal Department of the Ministry of Foreign Affairs of Estonia, Ms Kerli Veski on 15 February 2017 in response to the author's information request no. 4-4/813-1.

${ }^{75}$ Comment obtained from the advisor of the Legal Department of the Ministry of Foreign Affairs of Estonia, Mr Jaanus Kirikmäe on 13 October 2020 in response to the author's information request no. 4-4/5063.

${ }^{76}$ See above section entitled 'The Vironia Incident in the Gulf of Finland and Its Aftermath'.

${ }^{77}$ For a description of the Kerch Strait incident, see, e.g., the Case concerning the detention of three Ukrainian naval vessels (Ukraine v. Russian Federation), ITLOS Order of 25 May 2019, at paras. 30-32.
} 
that consider such requirements to breach the passage regime of the Russian Arctic straits under the LOSC. ${ }^{78}$

The Vironia incident bears resemblance to the 2018 Kerch Strait incident in that they both appear to have been provoked by the Russian Federation to serve as a policy instrument in response to a specific development that the Russian Federation perceives as strongly contradicting its geopolitical interests. The Vironia incident seems to have been triggered by the relocation of a Soviet Union's war memorial and the following unrest among the Russianspeaking minority in Tallinn, while the general ramification of the Kerch Strait incident is intertwined with the change of government in Ukraine. The epicentre of both incidents may have been temporally limited (the Vironia incident in 2007 and the Kerch Strait incident in 2018), but they have had a long-lasting effect on international navigation in the relevant maritime area. Estonia and Finland have downplayed the Vironia incident by not using publicly any diplomatic measures to resolve the still continuing deadlock regarding impediments that the Russian Federation has set to the north-south passage of a commercial ferry line through its territorial sea. Ukraine, on the other hand, initiated two arbitration proceedings (currently on-going) to challenge the legality of the Russian Federation's restrictions on the passage of ships to and from the Sea of Azov. ${ }^{79}$

In the Black Sea region, the Russian Federation has hampered not only the access of Ukrainian-flagged ships, but also third State commercial ships to the Sea of Azov. In its resolution of 25 October 2018 the European Union (EU) Parliament condemned the situation in the Sea of Azov, noting 'the excessive stopping and inspection of commercial vessels, including both Ukrainian ships and those with flags of third-party states, including ships under flags of various EU Member States'. ${ }^{80}$ Thus, the EU has reacted before when ships sailing under the flags of its Member States have been negatively impacted by the Russian Federation's practice of setting navigation restrictions that contradict the interests of the EU. In view of ensuring navigational rights and freedoms also in the Baltic Sea, Finland, Estonia, and the EU should consider objecting to the Russian Federation's refusal to grant to a commercial ferry line the right of innocent passage for making a north-south crossing of the Gulf of Finland proper, since a permit-based passage regime appears to lack a legal basis under the LOSC.

According to the EU Maritime Security Strategy, the strategic maritime security interests of the EU and its Member States are, inter alia, ' $[\mathrm{t}]$ he preservation of freedom of navigation, the protection of the global EU supply chain and of maritime trade, the right of innocent and transit passage of ships and the security of their crew and passengers'. ${ }^{81}$ The Vironia incident demonstrates that if restrictions on the passage rights of foreign ships render it practically impossible to operate a commercial ferry line between the ports of the EU Member States, then this has dire implications also to the EU free movement of persons and goods, and thereby to the EU single market.

\footnotetext{
${ }^{78}$ See, e.g., the protest of the United States: 'Russia - Northern Sea Route' in CD Guymon (ed), Digest of United States Practice in International Law (United States Department of State, Washington DC, 2015) 526-528; see further on the Russian Federation's claims, e.g., JJ Solski, 'Russia' in RC Beckman, T Henriksen, KD Kraabel, EJ Molenaar and JA Roach (eds), Governance of Arctic Shipping: Balancing Rights and Interests of Arctic States and User States (Brill, Leiden/Boston, 2017) 173-216, at pp. 192-197.

${ }^{79}$ See Annex VII Arbitral Tribunal, Dispute concerning Coastal State Rights in the Black Sea, Sea of Azov, and Kerch Strait (Ukraine v. The Russian Federation), Permanent Court of Arbitration (PCA) Case No. 2017-06 available at https://pca-cpa.org/en/cases/149/; accessed 12 October 2020; Annex VII Arbitral Tribunal, Dispute concerning the Detention of Ukrainian Naval Vessels and Servicemen (Ukraine v. The Russian Federation), PCA Case No. 2019-28 available at https://pca-cpa.org/en/cases/229/; accessed 12 October 2020.

${ }^{80}$ European Parliament resolution of 25 October 2018 on the situation in the Sea of Azov, No 2018/2870(RSP), at p. 1.

${ }^{81}$ Council of the European Union, European Union Maritime Security Strategy (EU, Brussels, 2014) 6-7.
} 


\section{Conclusion}

All ships entering the Russian Federation's maritime area in the Gulf of Finland from the west, including by crossing the Estonian-Russian maritime boundary, are required to obtain prior authorisation from the Russian VTS centre. The Russian Federation refused to grant its permit for a ferry line Vironia to operate between the Sillamäe Port in eastern Estonia and the Kotka Port in eastern Finland for which she had to cross the Russian Federation's territorial sea in the centre of the Gulf of Finland proper. This caused the closure of the commercial ferry line in 2007.

The Vironia incident indicates that the Russian Federation hampers the right of innocent passage in relation to foreign ships that need to make regular north-south crossing of the Gulf of Finland proper via its territorial sea in the Gulf of Finland. The permit-based passage regime is still the main obstacle for relaunching the ferry line between the Estonian and Finnish ports in the Gulf of Finland proper.

The Vironia incident and its repercussions in the Gulf of Finland region follow a pattern of the Russian Federation's similar practice in imposing restrictions on international navigation in its maritime areas. Such unilaterally imposed restrictions have affected shipping also in the Kerch Strait and the Sea of Azov, as well as the Northern Sea Route in the Arctic Ocean. The Vironia incident and the Kerch Strait incident exemplify the Russian Federation's readiness to close its adjacent maritime areas to international navigation, resorting occasionally to discriminatory practices. This behaviour appears to have its roots in the Soviet Union's practice of applying the doctrine of mare clausum to its adjacent maritime areas prior to the 1989 Jackson Hole statement. 